\title{
IMAGENS DO PETROCENO: HABITABILIDADE E RESISTÊNCIA QUILOMBOLA NAS INFRAESTRUTURAS DO PETRÓLEO EM MANGUEZAIS DO RECÔNCAVO BAIANO
}

Rafael Palermo Buti (1) $ه$

Universidade da Integração Internacional da Lusofonia 


\section{RESUMO}

Neste ensaio fotoetnográfico, trago imagens e narrativas do petroceno, entendido como a infraestrutura do petróleo nas paisagens de manguezal do Recôncavo Baiano. Tomando como referência o debate sobre o antropoceno, pretendo contar histórias sobre os efeitos da cadeia petroleira nos territórios quilombolas e pesqueiros da região, mostrando formas de precarização, habitabilidade e modos de engajamento dos quilombolas e pescadores artesanais. A intenção é contribuir para o debate público sobre os efeitos da contaminação da cadeia de exploração de petróleo nas áreas de manguezal, fomentando os direitos de reparação dos pescadores artesanais e a recuperação dos seus ambientes de vida, bem como a inclusão de suas perspectivas nas políticas de conservação e recuperação deste ecossistema.

Palavras-chave: manguezal; petróleo; comunidades quilombolas; antropoceno; racismo ambiental.

\section{PETROCENE IMAGES: HABITABILITY AND QUILOMBOLA RESISTANCE IN OIL INFRASTRUCTURE IN MANGROVES IN THE RECÔNCAVO BAIANO}

\section{ABSTRACT}

In this photoethnographic essay, I bring images and narratives from the petrocene, understood as the oil infrastructure in the mangrove landscapes of Recôncavo Baiano. With it, I intend to tell stories about the effects of the oil supply chain on fishing territories, showing precariousness, habitability and ways of engaging quilombola and artisanal fishermen in the region. Taking the Dom João quilombo as a reference, the intention is to contribute to the public debate on the effects of contamination caused by the oil supply chain in the mangrove areas, promoting the reparation rights of artisanal fishermen and the recovery of their living environments, as well as the inclusion of their perspectives in the conservation and recovery policies of this ecosystem.

Keywords: mangrove; oil; quilombola communities; anthropocene; environmental racism.

\section{IMÁGENES DEL PETROCENO: HABITABILIDAD Y RESISTENCIA QUILOMBOLA EN LA INFRAESTRUCTURA PETROLERA EN LOS MANGLARES DEL RECÔNCAVO BAIANO}

\section{RESUMEN}

En este ensayo foto-etnográfico, traigo imágenes y narrativas del petroceno, entendido como la infraestructura del petróleo en los paisajes de manglar del Recôncavo Baiano. Con ello, pretendo contar historias de los efectos de la cadena petrolera en los territorios pesqueros, mostrando las formas de precarización, habitabilidad y modalidades de envolvimiento de los quilombolas y pescadores artesanales de la región. Tomando como referencia el quilombo Dom João, la intención es contribuir al debate público sobre los efectos de la contaminación de la cadena de explotación petrolera en las áreas de manglares, promoviendo los derechos de reparación de los pescadores artesanales y la recuperación de sus ambientes de vida, así como la inclusión de sus perspectivas en las políticas de conservación y recuperación de este ecosistema.

Palabras clave: manglares; petróleo; comunidades quilombolas; antropoceno; racismo ambiental. 


\section{CONSTRUINDO HÁBITOS DE OBSERVAÇÃO PARA UMA ECO-HISTÓRIA-DE-NOVO}

Discorrendo sobre uma área de mineração abandonada no centro da Jutlândia, Dinamarca, Ana Tsing (2019a) afirma que humanos raramente controlam os efeitos das perturbações nas paisagens, no sentido de planejar seu gerenciamento. Segundo esta autora, as perturbações derivadas "são geralmente as sobras involuntárias das atividades, nas quais as consequências na paisagem são dificilmente pensadas" (Tsing 2019a:154).

Lugares como campos de mineração desativados são áreas onde a vida deve recomeçar, depois de exterminada. Por isso, Tsing sugere que pesquisadores construam "hábitos de observação" para contar o que se pode chamar de "eco-histórias-de-novo", referindose a novos ecossistemas que surgem das ruínas das infraestruturas imperiais e industriais. O imperativo da morte é composto pelo ciclo da vida, abrindo possibilidade para habitabilidades ressurgentes: entendidas como o trabalho de muitos organismos negociando suas diferenças para forjar ajuntamentos multiespécies em meio aos distúrbios de paisagens arruinadas (Tsing 2017).

Por estar inscrita na história da exploração de petróleo comercial no Brasil desde os anos 1950, a cidade de São Francisco do Conde, localizada no
Recôncavo Baiano, deixou e deixa nas paisagens de manguezal rastros de eco-histórias-de-novo ${ }^{1}$. Ali, perturbações lentas e rápidas, antigas e novas, produzidas pela cadeia de exploração, refino e escoamento do petróleo, conformam as paisagens de manguezal da cidade, constituindo lugares e modos de habitar (Buti 2019; Silveira \& Buti 2020). Guaiamuns-petroleiros, prainhas, aterros, ruínas, ruídos, tubulações, caminhões, caminhos, bases de exploração ativadas e abandonadas, cheiro de gás, cercas, especulação imobiliária, racismo ambiental e institucional são alguns dos efeitos dessa triste história inscrita nos lugares de vida de quem habita o manguezal, modelando os territórios pesqueiros de uma cidade que conjuga alta concentração fundiária, elevado Produto Interno Bruto (PIB), derivado dos royalties, e baixo Índice de Desenvolvimento Humano (IDH) (Sansone 2007; GeografAR 2015).

Este é o lugar de vida do quilombo Dom João, comunidade habitada por cerca de 80 famílias, que vivem da pesca artesanal e engajam estratégias de enfrentamento aos efeitos de longa e curta duração produzidos pela indústria petroleira. As eco-histórias-de-novo que trago conjugam textos curtos e imagens fotográficas de episódios e lugares percorridos por quem faz do mangue seu

1 O município está localizado na porção norte da Baía de Todos os Santos a $77 \mathrm{~km}$ de Salvador. Sobre a história do petróleo na Bahia e em São Francisco do Conde, ver Viana Filho (1984) e Brito (2008). 
território de vida. Eles são resultado de minhas atividades de pesquisa, extensão e ensino como professor do Instituto de Humanidades e Letras, da Universidade da Integração Internacional da Lusofonia Afro-brasileira (UNILAB), sediado no campus do Malês, localizado em uma área de encosta de manguezal contígua a Dom João².

Com este ensaio fotoetnográfico, pretendo provocar o debate público sobre os direitos das comunidades pesqueiras em áreas de manguezal afetadas pelo petróleo. A ênfase midiática nas "praias do Nordeste" durante o catastrófico (e cuja causa ainda é enigmática) vazamento do petróleo trazido pelos mares do Atlântico para a costa brasileira, a partir de agosto de 2019, reforçou a invisibilidade dos efeitos da contaminação nas áreas de manguezal, o silenciamento das vozes e das perspectivas de pescadores e marisqueiras, bem como a inoperância do poder público sobre a realidade de quem vive neste ecossistema (Intervozes 2020)3. Embora o petróleo vaze nos manguezais da Baía de Todos os Santos há mais de 50 anos, e embora haja pesquisa sobre os efeitos da contaminação (Hatje et al. 2009), este debate é incipiente na esfera pública no que concerne à efetivação dos direitos socioambientais das comunidades.

Manguezais são ecossistemas sensíveis aos efeitos da contaminação por petróleo e, por isso, carecem de atenção especial por parte do poder público: é também uma questão de saúde pública e do direito do trabalhador, pautas importantes levantadas pelo Movimento dos Pescadores e Pescadoras Artesanais (MPP) e pelo Conselho Pastoral da Pesca (CPP) da Bahia. Boa parte dos vazamentos e das tragédias que testemunhei nesses poucos anos de presença nos manguezais não é acompanhada, e sequer reconhecida, pelos órgãos responsáveis em nível municipal, estadual e federal. Poucos são os planos de recuperação das áreas contaminadas, e raras são as situações de reparação aos danos causados aos pescadores e às marisqueiras.

Minha intenção com a publicação de imagens e histórias associadas é explorar acontecimentos e perspectivas de alguns pescadores diante dos modos de perturbação da cadeia petroleira em seus lugares de vida. Como veremos, há perturbações lentas e de longa duração, resultado de vazamentos ocorridos há décadas. Há perturbações rápidas

2 Este artigo é desdobramento de uma comunicação feita durante a VII Reunião de Antropologia da Ciência e Tecnologia (REACT), realizada no mês de maio de 2019, em Florianópolis, Santa Catarina (Buti 2019). As imagens foram capturadas por meio da câmera de celular Samsung (modelo J5 Prime), em diferentes contextos de pesquisa e atividades pedagógicas, entre 2017 e 2020.

3 Para um panorama da catástrofe, ver Soares et al. (2020). Sobre a relação entre o vazamento do petróleo no Atlântico e as áreas de manguezal, ver Gragnani (2019). 
e de curta duração, referentes a um vazamento que destrói o lugar em poucos dias. Há rupturas, como os aterros sobre o mangue, que exterminam a habitabilidade de algumas espécies para produzir outras habitabilidades. Há poços de exploração ativados e desativados, ruínas grandes e pequenas, pedaços de construção abandonados em áreas de pesca. Há os manguezais mortos, conhecidos como prainha, onde bosques de árvores de mangue vermelho (Rhizophora mangle) e mangue branco (Laguncularia racemosa) foram radicalmente exterminados, dando lugar a uma área deserta, que também se transforma aos poucos. Tudo isso é manguezal hoje, é território pesqueiro, lugar percorrido e habitado pelas múltiplas vidas que o compõem. Tudo isso é o petroceno.

\section{O VAZAMENTO DE PETRÓLEO E A INDEPENDÊNCIA DA BAHIA}

Quinta-Feira, madrugada de 16 de maio de 2018. Um duto da Petrobras se rompe nas imediações do quilombo Dom João, contaminando áreas residenciais, roças e o manguezal (Figura 1). Ali, ambientes habitados por crustáceos, peixes, plantas,

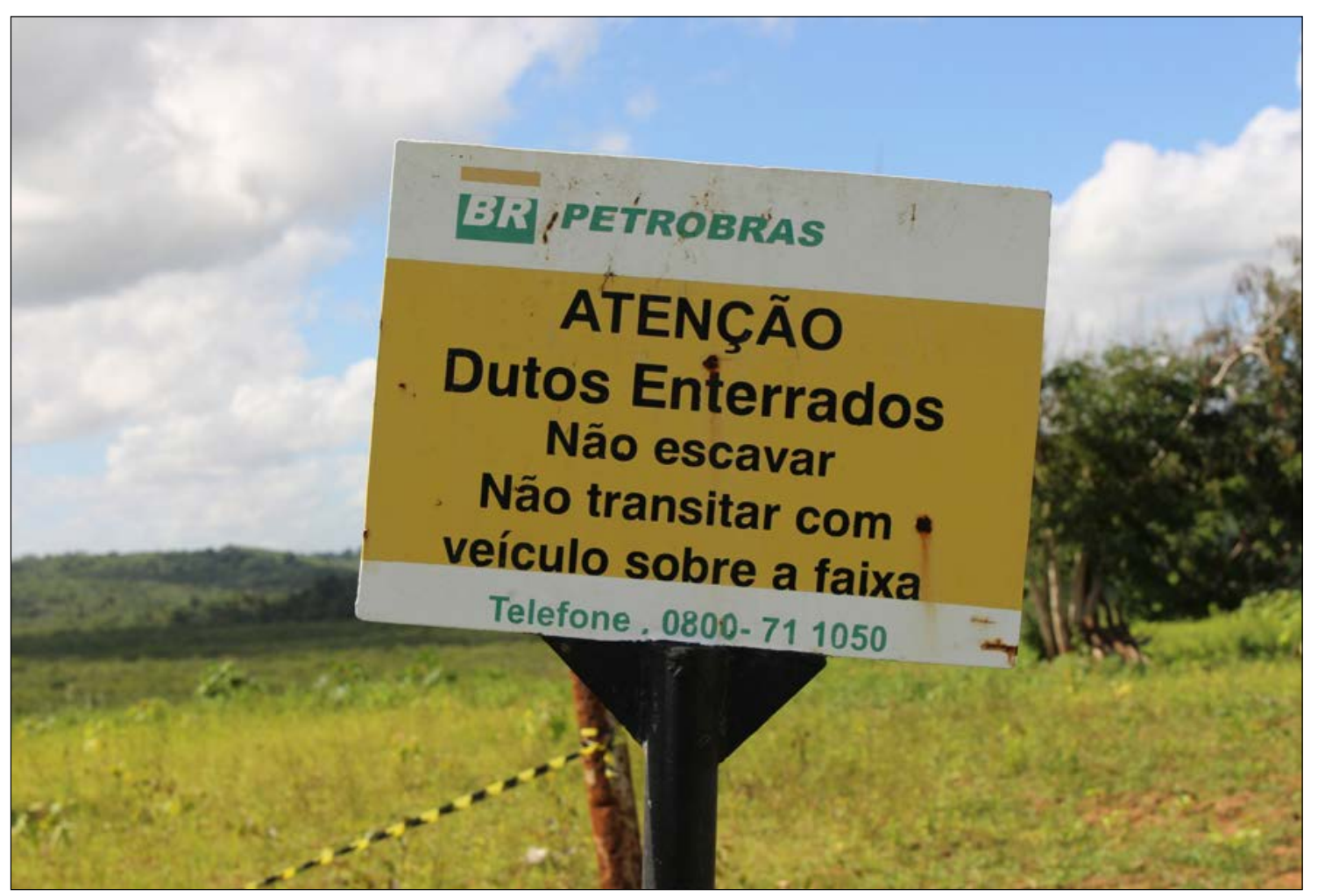

Figura 1 - Placa informando os dutos de onde vazou o petróleo, em maio de 2018. Ao fundo, o manguezal de Dom João, para onde o petróleo desceu. Esta imagem foi tirada em 24 de maio de 2018, durante uma atividade da UNILAB. Fonte: arquivo do PROEX/UNILAB. Foto: Rafael Palermo Buti (2018). 
pássaros, pescadores, marisqueiras e rios amanhecem cobertos de óleo e com a cor escurecida. A subida da maré, no dia seguinte, espalhou o petróleo a outros pontos do manguezal, desaguando na Baía de Todos os Santos. De barco e a pé, alguns moradores de Dom João passam a registrar a catástrofe, produzindo dados para subsidiar as denúncias junto aos órgãos responsáveis. Imagens do mangue preto, com caranguejos mergulhados no petróleo, peixes e aratus mortos, passam a circular pelas redes sociais.

Responsável por transportar o petróleo extraído da Trincheira do Marapé (nome oficial de uma base de exploração no manguezal do Marapé) à refinaria Landulpho Alves, a "linha do petróleo" (como são chamados os dutos) rompeu, por conta do desabamento de um aterro (Figura 2). As fortes chuvas de maio foram, segundo moradores, os fatores do desabamento, e do consequente rompimento da linha e espalhamento do petróleo pelo morro e mangue abaixo.

Antes de chegar às áreas residenciais, roças e manguezal em Dom João, o petróleo derramado percorreu os canaviais que separam a base petroleira de Marapé das áreas de moradia da comunidade. A partir de então, o tom esverdeado, amarelado e amarronzado dos canaviais, que sempre compuseram as paisagens de massapê do Recôncavo desde o contexto colonial, dividia com o petróleo sua coloração em Dom João (Figura 3).

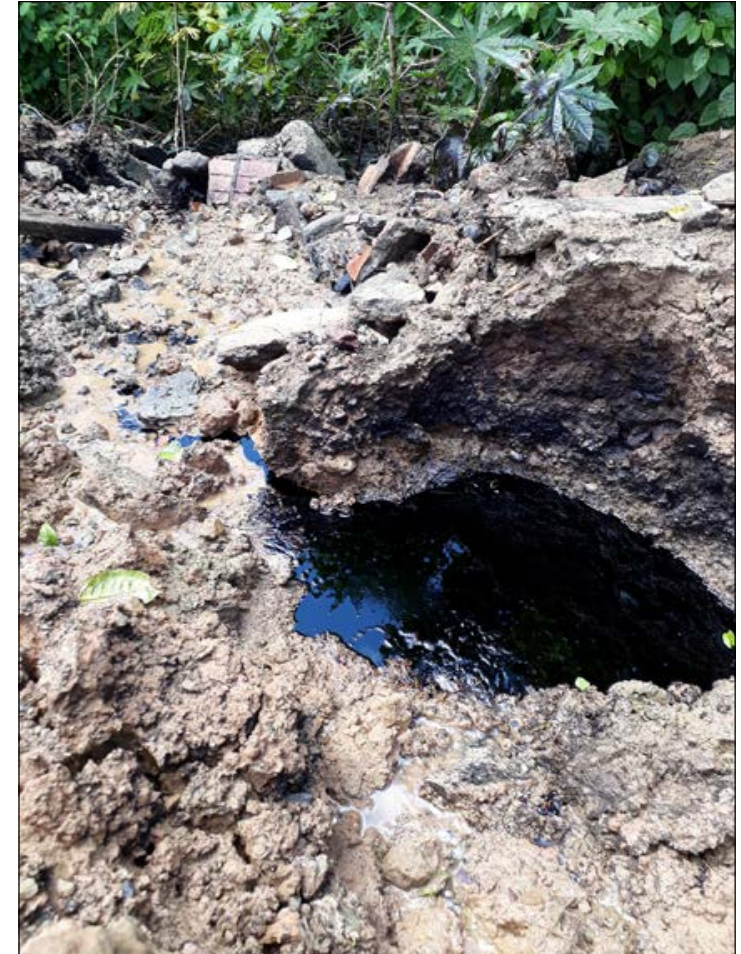

Figura 2 - Fonte de onde jorrou o petróleo vazado em maio de 2018, por conta do desabamento de um aterro, e o rompimento de um duto. A imagem mostra o petróleo vazando sobre os destroços, registrada em 19 de maio de 2018, três dias após o vazamento. Foto: Rafael Palermo Buti (2018).

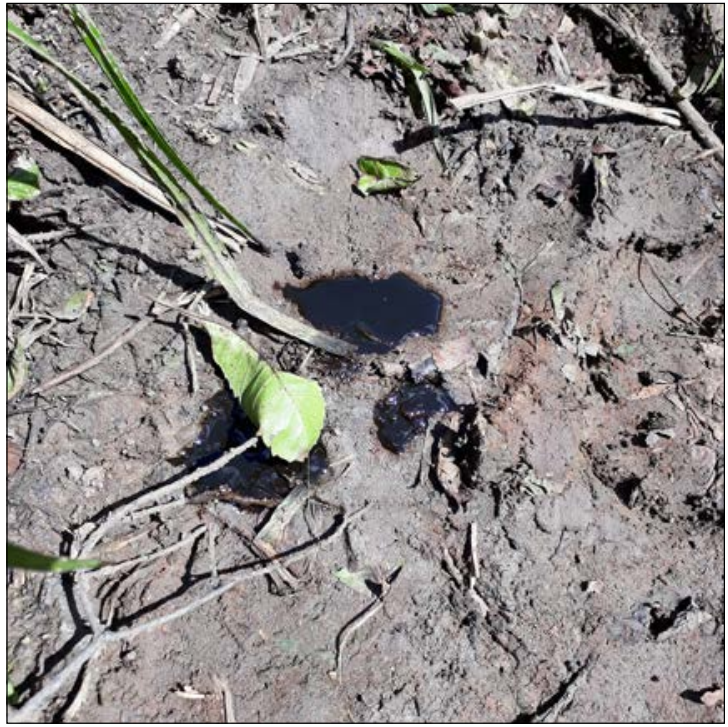

Figura 3 - Rastros do petróleo vazado sobre o manguezal. Foto: Rafael Palermo Buti (maio 2018). 
Um dia depois, a Petrobras iniciava a tentativa de descontaminação e limpeza do mangue, o que dava à paisagem estuarina uma nova composição: em lugar de marisqueiras, gaiamunzeiros e caranguejeiros ocupando, com seus petrechos de pesca, o manguezal junto às espécies, homens vestidos com capa laranja e chapéu de proteção branco faziam ali a contenção e a sucção do petróleo, em meio a um cheiro bastante forte (Figura 4). Impedidos de adentrar no mangue, os moradores assistiam à distância os trabalhadores da Petrobras instalarem barreiras de contenção do óleo, além do manuseio de um sugador conectado a um caminhão, estacionado em uma estrada de chão batido na beira de mangue. O movimento e o barulho eram intensos. O cheiro, bastante forte, era sentido na estrada de rodagem que liga o município de São Francisco do Conde a Candeias. No dia 2 de julho do mesmo ano, a Associação Quilombola Dom João publicava uma carta aberta, assinada por entidades e grupos parceiros, denunciando o ocorrido (Associação Quilombola Porto Dom João 2018). A data escolhida pela comunidade não foi aleatória: 2 de julho é o dia comemorativo da independência da Bahia, evento anualmente ritualizado por sua população, que celebra a expulsão das tropas lusitanas de Madeira Melo do Brasil, nos idos de 1823.

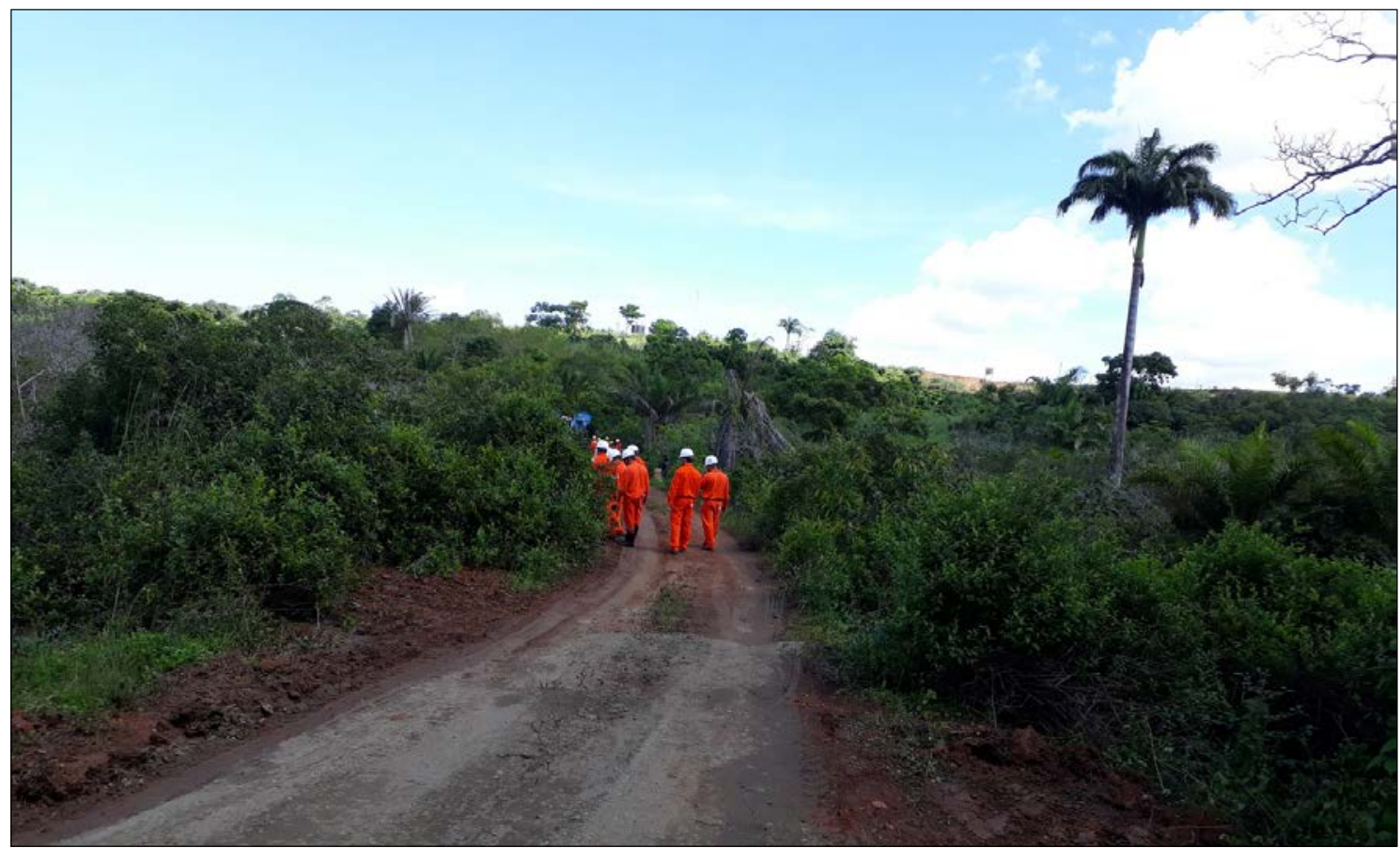

Figura 4 - Homens entrando no manguezal para preparar o processo de sucção do petróleo. Foto: Rafael Palermo Buti (maio 2018). 
Segundo o historiador Joel Rufino dos Santos, a data remonta ao "dia em que o povo ganhou" (nome de seu livro homônimo), em referência aos episódios que culminaram na expulsão definitiva dos portugueses do Brasil (J. Santos 1979). Para este autor, o apagamento das histórias da independência da Bahia nos cânones de uma história oficial da independência nacional é correlata ao apagamento das histórias das lutas antiescravistas nos cânones de uma história oficial da abolição da escravidão. Em ambas, são as figuras da elite imperial (Dom Pedro e Princesa Isabel) quem, em um ato benevolente e sem atritos, figuram representadas como aquelas que concedem a dádiva ao país (sua independência e liberdade), deslocando os personagens reais (o povo) ao polo de uma passividade, invisibilidade e cordialidade próprias, embebidas no mito da democracia racial.

Na carta de Dom João, o quilombo (este lugar consagrado pela ideologia nacional como o símbolo maior de resistência antiescravista) recupera a data para reivindicar sua independência do petróleo e da precariedade imposta pelas infraestruturas petroleiras. Ao fazê-lo, coloca-se como defensor do mangue e acusa os órgãos ambientais de negligência, por, durante décadas, contribuírem para a produção da morte nos lugares de vida e pesca de sua população. No documento, a Associação coloca os pescadores e as pescadoras de Dom João como os "guardiões" e protetores das áreas de manguezal, lugar da resistência, liberdade e independência do povo negro, que sempre viveu nos ditames da "mãe maré".

\section{HISTÓRIAS EM RUÍNAS}

A cena do vazamento em Dom João evidencia um caso muito concreto do impacto provocado pelas perturbações por petróleo nos ambientes que conformam os territórios pesqueiros no Recôncavo, justamente no período em que o próprio petróleo e o valor dos seus derivados estavam na pauta temática da opinião pública brasileira. Foi no dia 20 de maio daquele ano, três dias após o vazamento no Marapé, que se deflagrou o movimento de paralisação dos caminhoneiros e motoristas pelas estradas do Brasil: enquanto estes reivindicavam a flexibilização das tarifas de pedágio e a diminuição do valor do petróleo "refinado" para o transporte dos caminhões e automóveis, o território de Dom João recebia, gratuitamente e aos jorros, um petróleo "puro", com poder de matar as muitas vidas que o conformam. Para o caso da paralisação, a cobertura da mídia era completa; para o de Dom João, não existia.

Não era a primeira vez que um vazamento marcava essa relação direta, e desigual, do petróleo para com os moradores de Dom João. Pouco mais de um ano antes do vazamento 
no Marapé, em fevereiro de 2017, acompanhei um dos seus habitantes em uma pescaria de guaiamum (Cardisoma guanhumi), crustáceo que vive nas áreas do entorno da parte mais úmida dos manguezais, nos "costeiros", como são conhecidos na cidade esses ambientes de transição entre manguezal e florestas (Figura 5). $\mathrm{Na}$ ocasião desta pescaria realizada próxima a

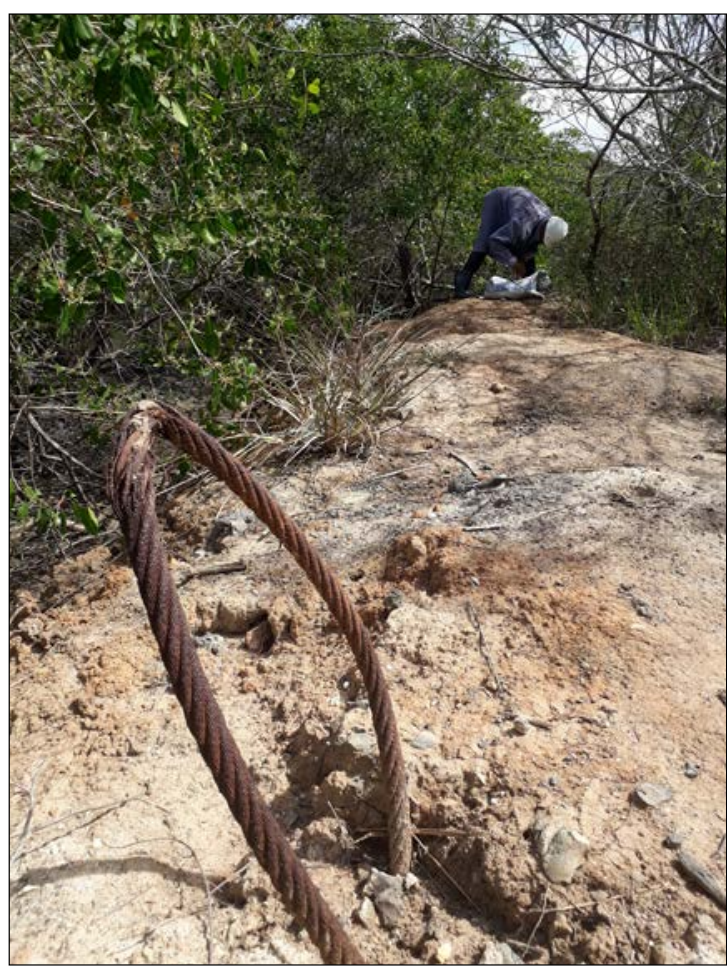

Figura 5 - Gaiamunzeiro é como são conhecidos os pescadores de guaiamum. Ao fundo desta imagem, capturada em fevereiro de 2018, um gaiamunzeiro prepara a ratoeira em uma toca aberta pelo animal em área de aterro. À frente, vê-se um apoio de ferro incrustado do território de pesca: trata-se das sobras de um ponto de exploração de petróleo abandonado. Foto: Rafael Palermo Buti (2018).
Dom João, o pescador se preparava para recolher as últimas "ratoeiras"4 que armara nas tocas de guaiamum. Ao abrir uma destas, nos deparamos com o que ele mesmo denominou de "guaiamum petroleiro": um guaiamum de coloração preta, com uma consistência oleaginosa e um cheiro bastante forte, fruto da contaminação por petróleo na área ao fundo do buraco onde o animal morava, com profundidade em torno de 2 metros

Este petróleo que ocupava o fundo do buraco onde vivia o "guaiamum petroleiro" não foi ali parar por decorrência de um vazamento recente, como no caso do Marapé. Tratava-se, ao contrário, de um petróleo vazado há décadas, quando o então pescador, ainda criança e morador do local, ouvira falar do rompimento de um duto na estrada vizinha, o que ocasionou, de noite, uma grande explosão e a descida do petróleo rio abaixo, em direção à Baía de Todos os Santos. Conta-se que a descida do petróleo pelas águas foi percebida por alguns moradores, em decorrência de um fogo de 5 metros de altura, que descia pelo rio, além do forte cheiro que exalava. Eis as condições socioambientais que fizeram com que existisse um "guaiamum petroleiro" décadas depois.

De uma forma importante, a história do petróleo na cidade está inscrita no corpo do animal: seu nome

4 As ratoeiras são o apetrecho utilizado em vários locais do Brasil para pescar o guaiamum. São armadilhas construídas pelos próprios pescadores, com materiais facilmente disponíveis em seu ambiente, incluindo uma estrutura cilíndrica, que pode ser feita com garrafas PET, canos de PVC, embalagens plásticas diversas, latas de óleo ou de leite. Ver Silveira \& Buti (2020). 
duplo, batizado pelo pescador, indica a condição híbrida de uma "natureza" atravessada por uma "cultura" da exploração dos recursos mediante os rastros do petróleo.

O que surpreende éo intervalo de tempo que separa este vazamento épico em relação ao dia do nosso encontro com o "guaiamum petroleiro": algo em torno de 40 anos. Há, portanto, uma memória social e uma história ambiental dos vazamentos, ambas ignoradas pela oficialidade, que prefere louvar a cadeia petroleira na cidade, lucrar com o dinheiro de seus royalties, sem criar mecanismos de proteção e preservação do manguezal e dos muitos corpos que o habitam.

O "guaiamum petroleiro" é incrivelmente resistente, não morreu contaminado, diferentemente do caranguejo encontrado por uma moradora de Dom João dias depois do vazamento do Marapé. Contara a senhora de mais de 70 anos, em uma reunião da Associação Quilombola Dom João, que, ao encontrá-lo morto pelo petróleo, teve que enterrá-lo, pela tristeza de ver seu corpo jogado na beira do quintal. Pescar um "guaiamum petroleiro" e enterrar um caranguejo evidenciam relações e afetos de pescadores e marisqueiras de Dom João nos ambientes de manguezal: diferentes formas de conviver, coabitar e cuidar da vida, em meio às finitudes impostas pela cadeia petroleira.

A pergunta que devemos fazer é: que tipos de seres e paisagens serão produzidos pelo vazamento de maio de 2018? Passados dois anos do desastre, parte da área contaminada pelo vazamento inicia um processo gradual de transformação, haja vista o ressecamento das árvores de mangue e a diminuição da ocorrência dos caranguejos. Estes são alguns marcadores do início de sua morte (Figura 6).

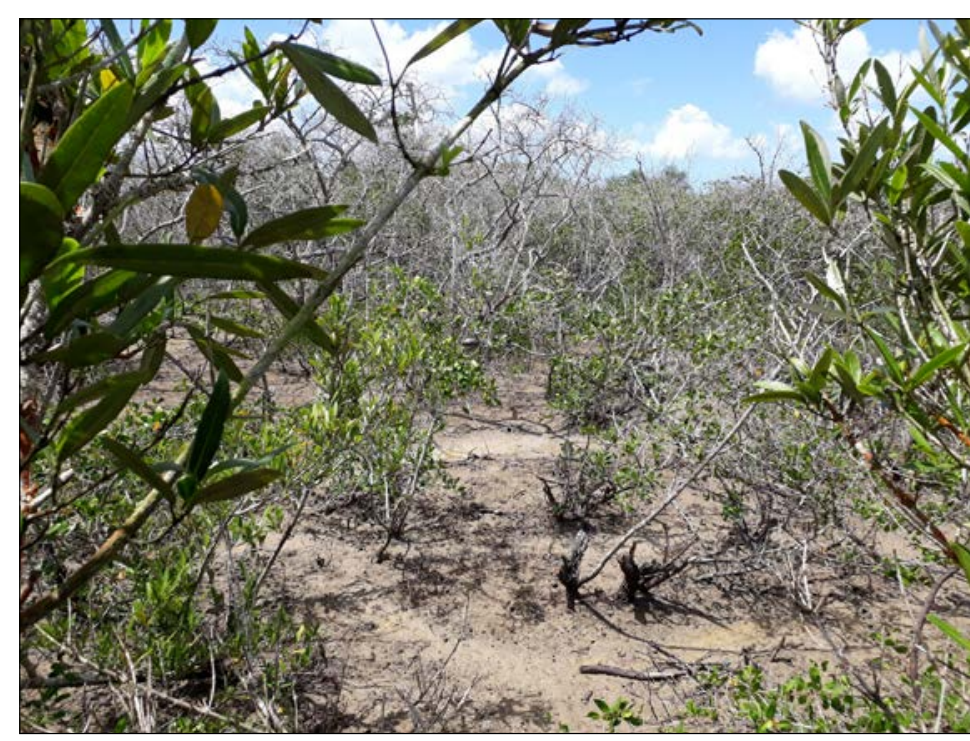

Figura 6 - Localidade de manguezal afetada pelo vazamento de petróleo de maio de 2018, capturada dezessete meses após o vazamento, em outubro de 2019. Nota-se que as árvores de mangue estão com suas folhas e troncos ressecados, indicando a morte em curso e a possibilidade de o lugar transformar-se em prainha. A ocorrência das espécies de crustáceos e moluscos está diminuindo aos poucos. Não existe

plano de recuperação dessa área previsto pela Secretaria Municipal de Meio Ambiente, Agricultura e Pesca (SEMAP), pelo Instituto do Meio Ambiente e Recursos Hídricos (INEMA) ou Instituto Brasileiro do Meio Ambiente e dos Recursos Naturais Renováveis (IBAMA), tampouco reparação aos pescadores e às marisqueiras que aí trabalhavam e de onde tiravam seu sustento. Foto: Rafael Palermo Buti (2019).

\section{4. "A MARÉÉ UMA SÓ”: CUIDAR E TER CUIDADO}

Engajar hábitos de observação para contar ecohistórias-de-novo implica estar atento às perspectivas e aos saberes locais. São os pescadores e pescadoras 
artesanais quilombolas os melhores conhecedores dos lugares, e os que mais diretamente conhecem e sofrem os efeitos perversos da perturbação e a desigual distribuição dos riscos ocasionados pelas infraestruturas do petróleo. São estes também quem tem engajado modos de cuidar do mangue e oferecido caminhos para a recuperação das áreas.

Em uma reunião sobre racismo ambiental nos territórios pesqueiros, organizada na sede do Conselho Pastoral dos Pescadores em setembro de 2018, em Salvador, uma liderança da comunidade quilombola de Acupe, Santo Amaro, ensinava sobre a influência das marés na produção da morte no mangue. Afirmava a senhora que a "maré é uma só", e que sua força, que dá vida às espécies e rege o ciclo dos peixes, mariscos, pescadores e marisqueiras, pode levar também à contaminação de um lugar ao outro. Isso explica a existência das prainhas em vários pontos dos manguezais, mesmo em locais não diretamente afetados por um vazamento (Figura 7). Isso também implica aos humanos a necessidade de cuidar do mangue diante do avanço das contaminações.

A mesma maré que produz a vida tem potência para levar à morte. As reflexões da pescadora quilombola lembram-nos as palavras de Ailton Krenak, recuperadas no texto de Alexandre Nodari (2018), quando este discorre sobre o sentido ambivalente do cuidado com o mundo: é necessário ter "cuidado com o mundo porque ele éfrágil e podemos destruí-lo, mas também, e ao mesmo tempo, precisamos ter cuidado com o mundo porque ele é perigoso e pode se vingar das nossas ações” (Nodari 2018:8).

O duplo sentido do cuidado nos leva ao que Isabele Stengers (2015) chama de o "tempo das catástrofes". Nele, "teremos que responder incessantemente pelo que fizemos diante de um ser implacável”, “Gaia”, cuja intrusão e indiferença determina o "devir monstruoso" (Stengers 2015:41) que se descortina, primeiramente e principalmente, às populações pobres do planeta,

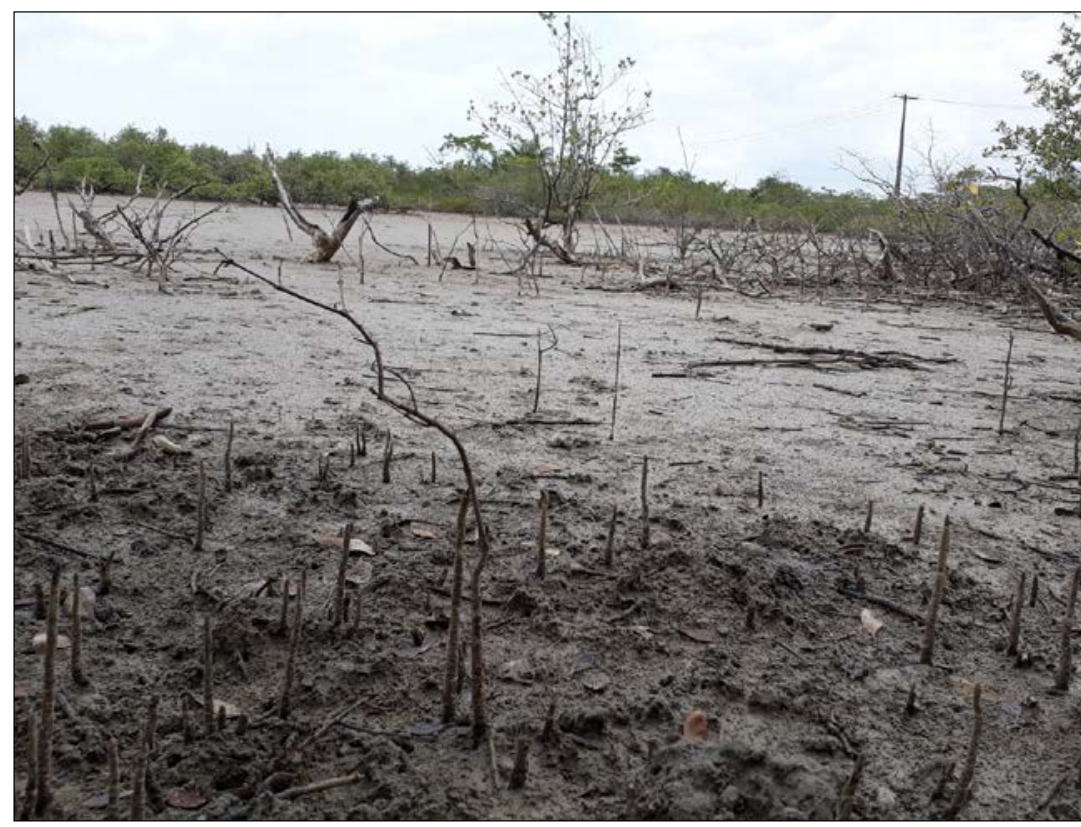

Figura 7 - Prainha no manguezal do Marapé. Esse é o efeito de décadas de exploração do petróleo nos manguezais. Muitas árvores de mangue vermelho morreram nesse local, que, em condições saudáveis, permitia ocorrência faunística e florística em abundância, como de moluscos e crustáceos. Na imagem, tirada em

fevereiro de 2018, vê-se raízes de mangue vermelho despontando. O manguezal ressurgirá na perturbação ou sua morte definitiva já está decretada pelo petróleo? Foto: Rafael Palermo Buti (2018). 
as que, justamente, não são as responsáveis pela catástrofe. Em São Francisco do Conde, a intrusão de Gaia é a intrusão do "guaiamum petroleiro" e seus devires monstruosos nas áreas de manguezal. Diante dela, os pescadores artesanais do quilombo Dom João e seus aliados travam algo parecido com o que Arturo Escobar (2015) chama de "luta ontológica”, entendida como a defesa dos muitos mundos que habitam o planeta, diante das crises ecológicas produzidas pelo grande mercado. Diante delas, pescadores e marisqueiras engajam o que Boaventura de Souza Santos, ao discorrer sobre modos de resistência no quilombo da Ilha de Maré, próximo a Dom João, entende como a possibilidade de "um outro mundo possível” (B. Santos 2017).

Ao nomear uma de suas bases de exploração de petróleo de trincheira do Marapé, a Petrobras assume a "luta ontológica". Boa parte do mangue ao redor da trincheira está morta, mas não vencida (Figuras 8 a 11). É possível ressurgir? Em uma atividade de "caminhaula", realizada para um curso no próprio Marapé quatro dias antes do vazamento do dia 16 de maio, Seu José, pescador de Dom João responsável pela dinâmica, disse que sim. Basta replantar o mangue de uma forma diferente da que os projetos de recuperação da Petrobras têm feito: com amor. Produzir mundos é também amar. O petróleo recém-vazado em Dom João foi dali extraído. Se a área recém-afetada virará uma prainha, só o futuro (e a maré) poderá dizer. De todo modo, a guerra (e a luta ontológica) está declarada.

\section{O PETROCENO: A INFRAESTRUTURA DO PETRÓLEO NOS MANGUEZAIS}

Chamo de petroceno a conformação do mundo do petróleo nos territórios pesqueiros da cidade, suas perturbações lentas e rápidas, inscritas nas paisagens de manguezal. O conceito surge como necessidade de localizar e nomear forças específicas do antropoceno, responsáveis pela catástrofe planetária que marca a presente época: quando o humano deixa de ser mero agente biológico para se tornar força geológica (Tsing 2019a). Petroceno vem ao encontro das reflexões de Donna Haraway (2015), em relação aos limites do conceito de antropoceno: sobretudo a aplicação generalizada da ideia de antropos a grupos que não somente não respondem pelas causas dos desastres ecológicos como engajam modos de recuperação e cura nos ambientes perturbados ${ }^{5}$.

5 Segundo esta autora, “capitaloceno" e "plantationceno" são termos que vinculam e corresponsabilizam mais diretamente o tipo de sistema-humanidade causador das catástrofes do tempo presente: colonialista, de monocultora, racista, escravista e capitalista. 


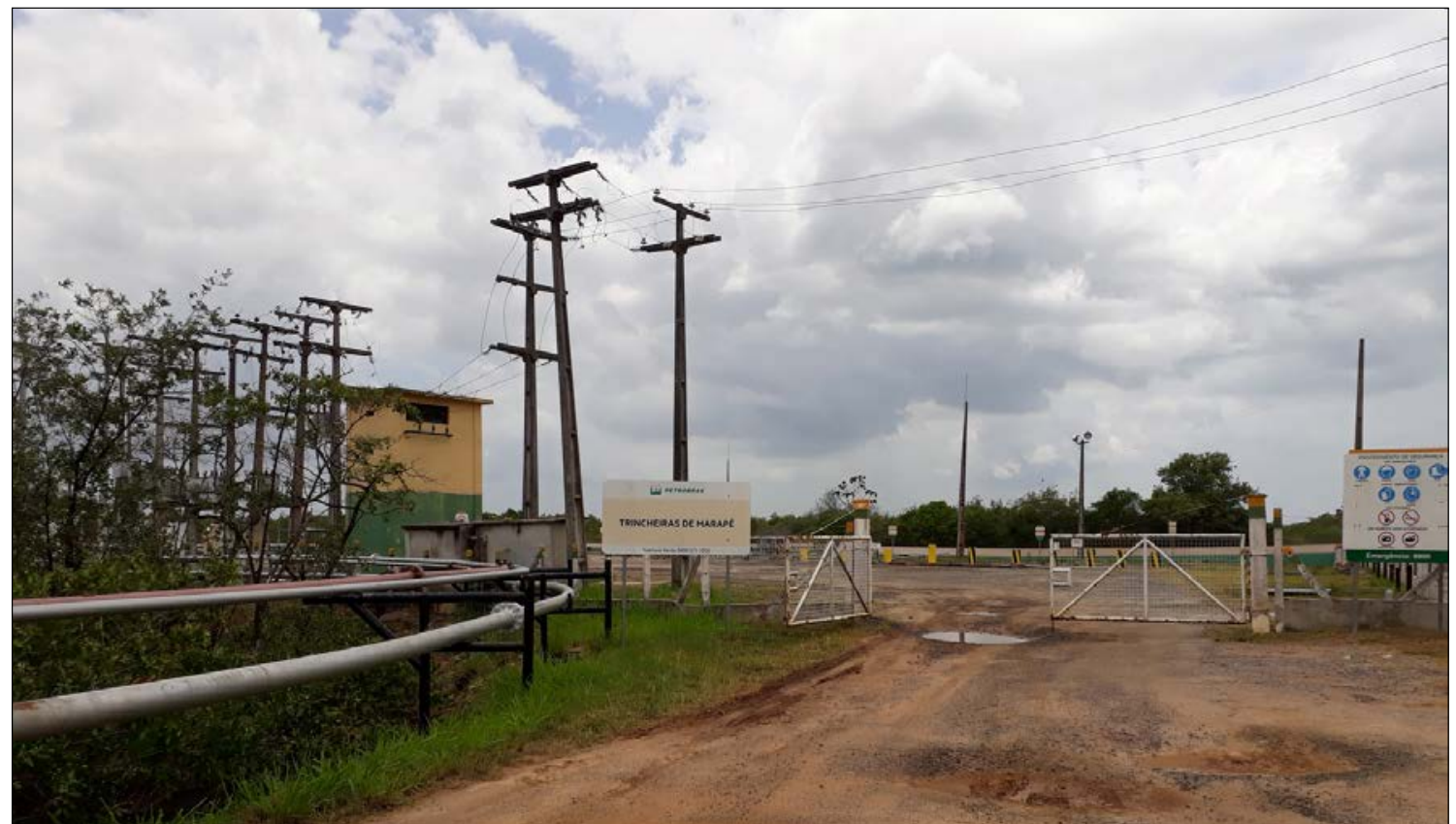

Figura 8 - Trincheira de Marapé, um dos pontos de exploração do petróleo. Os tubos à esquerda são chamados de "linhas" e levam o petróleo a um reservatório localizado em uma das entradas da cidade. Este reservatório é ligado por um sistema de linhas à refinaria Landulpho Alves, que, por sua vez, é conectada ao polo industrial de Camaçari e ao porto de Aratu. A Trincheira bombeia o petróleo do coração do mangue ao (fim do) mundo. Foto: Rafael Palermo Buti (2018).

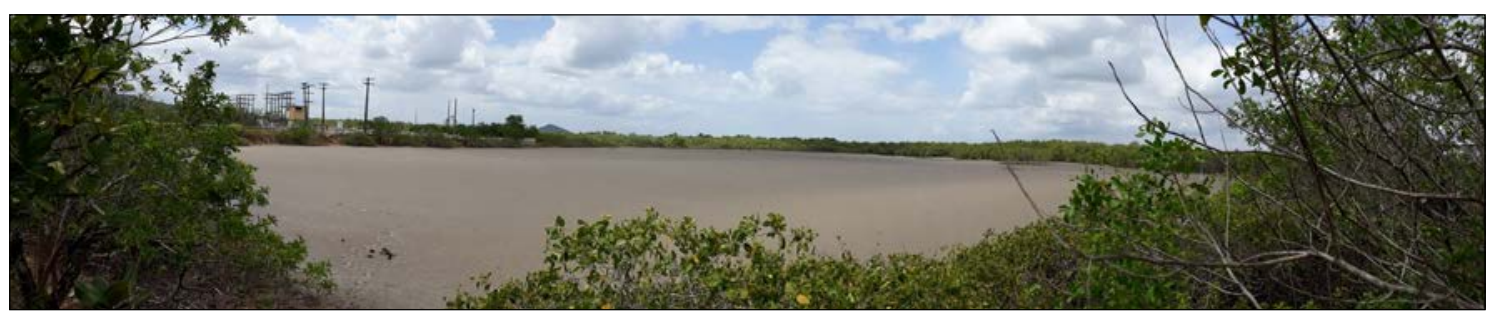

Figura 9 - Mangue morto pela Trincheira de Marapé, que está ao fundo. Este manguezal poderá ressurgir e fazer brotar novamente as muitas vidas que aí viviam? O que os órgãos ambientais responsáveis têm feito para recuperar o ecossistema manguezal? Pescadores e marisqueiras são indenizados pelos efeitos do petroceno em seus corpos?

Foto: Rafael Palermo Buti (fev. 2018).

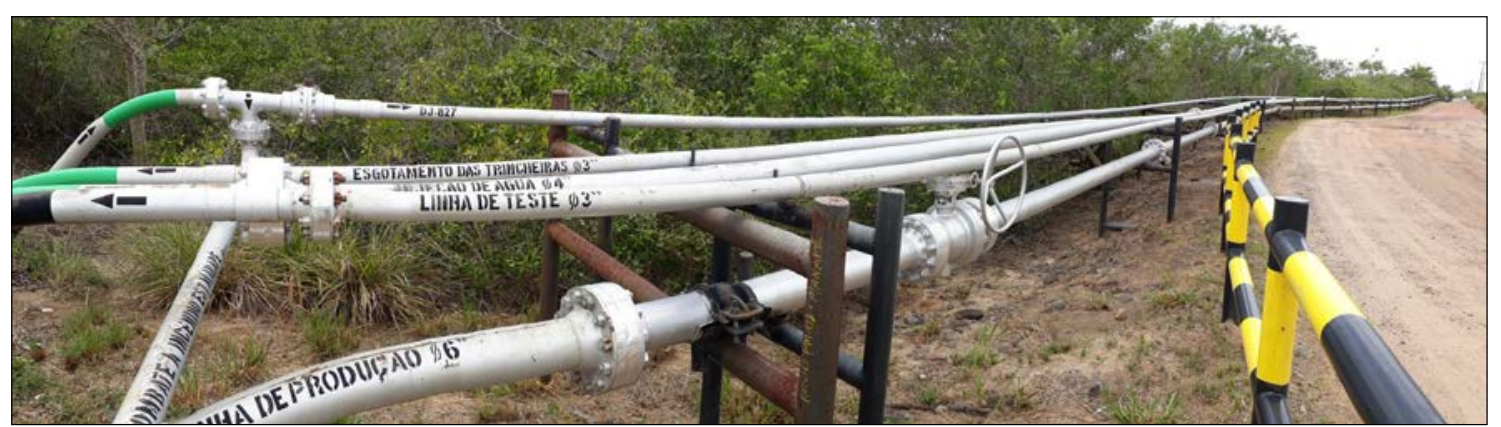

Figura 10 - Dutos que saem da Trincheira. São as veias do petróleo que ligam Marapé ao (fim do) mundo. Foto: Rafael Palermo Buti (fev. 2018). 


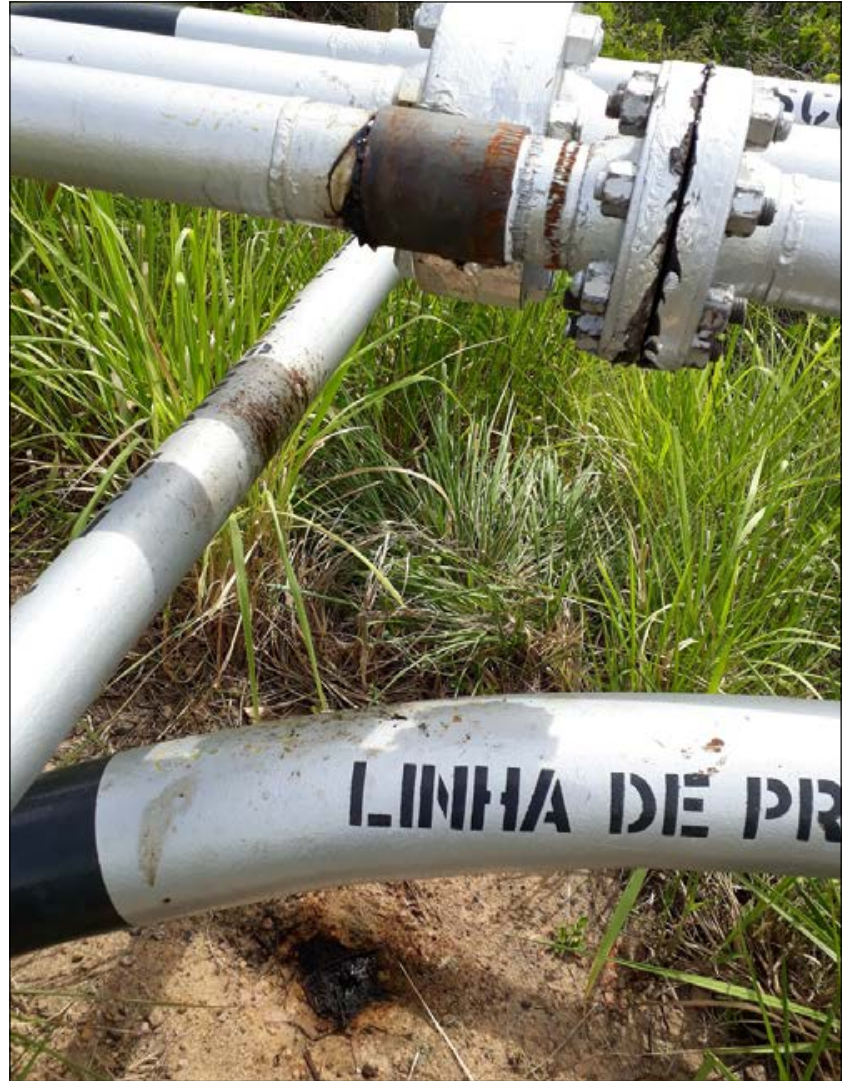

Figura 11 - Gotas de petróleo pingando no chão. Essa imagem foi captada durante uma atividade pedagógica em parceria com Dom João, em janeiro de 2020, em uma tubulação de petróleo que liga a Trincheira de Marapé à refinaria Landulpho Alves. Ela é um testemunho da precariedade da infraestrutura do petróleo nas áreas de manguezal, e um modo de captarmos formas de perturbação de longa duração quase imperceptíveis.

Foto: Rafael Palermo Buti (2020).

Petroceno é, portanto, uma modalidade do antropoceno, e surge para descrever as infraestruturas do petróleo na produção das paisagens nos manguezais do Recôncavo Baiano. Infraestrutura diz respeito aos projetos imperiais e industriais que alteram a terra, a água e a atmosfera, destruindo a habitabilidade dos lugares (Tsing 2019b). Segundo Tsing (2019b), os efeitos ferozes das infraestruturas imperiais e industriais são o próprio antropoceno. O que implica dizer que não há manguezal na cidade fora do efeito da cadeia do petróleo. Ali, territórios pesqueiros emergem das ruínas (Figuras 12 e 13).

Petroceno é também um dispositivo conceitual em prol dos direitos aos modos de vida nos territórios pesqueiros. Ele nasce a partir de uma necessidade de produzir, em Dom João, descrição sobre conflitos que envolvem dois inimigos históricos dos quilombos da região: as interdições de acesso à terra determinadas pelas figuras clássicas, personalizadas pelo poder senhorial (os fazendeiros e os donos das terras), e o racismo e o sacrifício ambiental, derivados

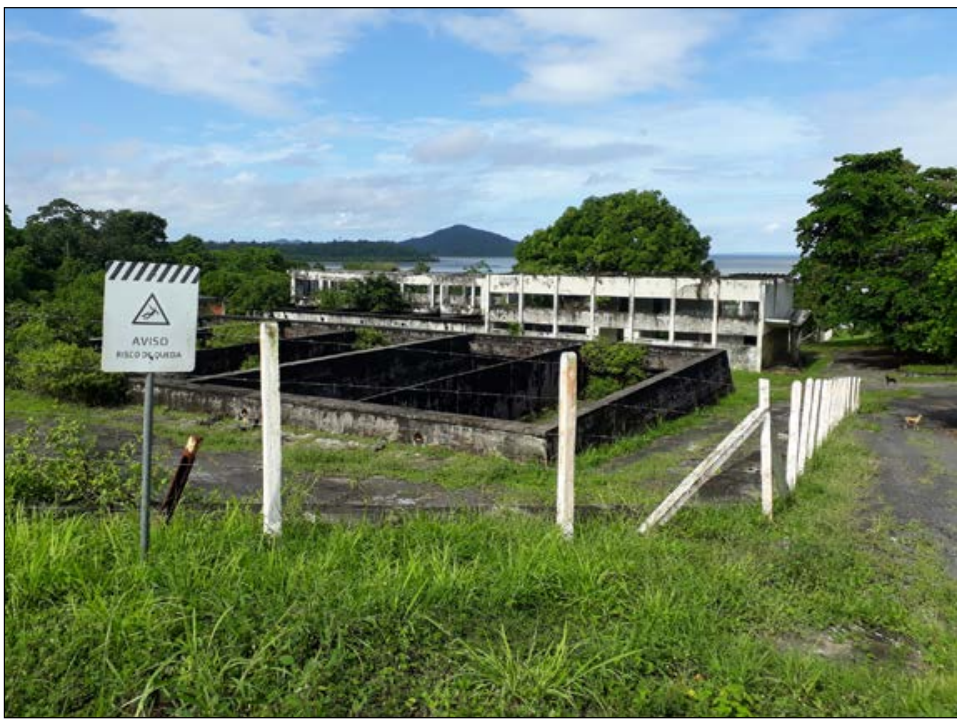

Figura 12 - Ruínas de uma estação de tratamento do petróleo na encosta de manguezal, que funcionou até os anos 1980 e, hoje, está abandonada. Ao fundo, as águas da Baía de Todos os Santos. Foto: Rafael Palermo Buti (maio 2019). 


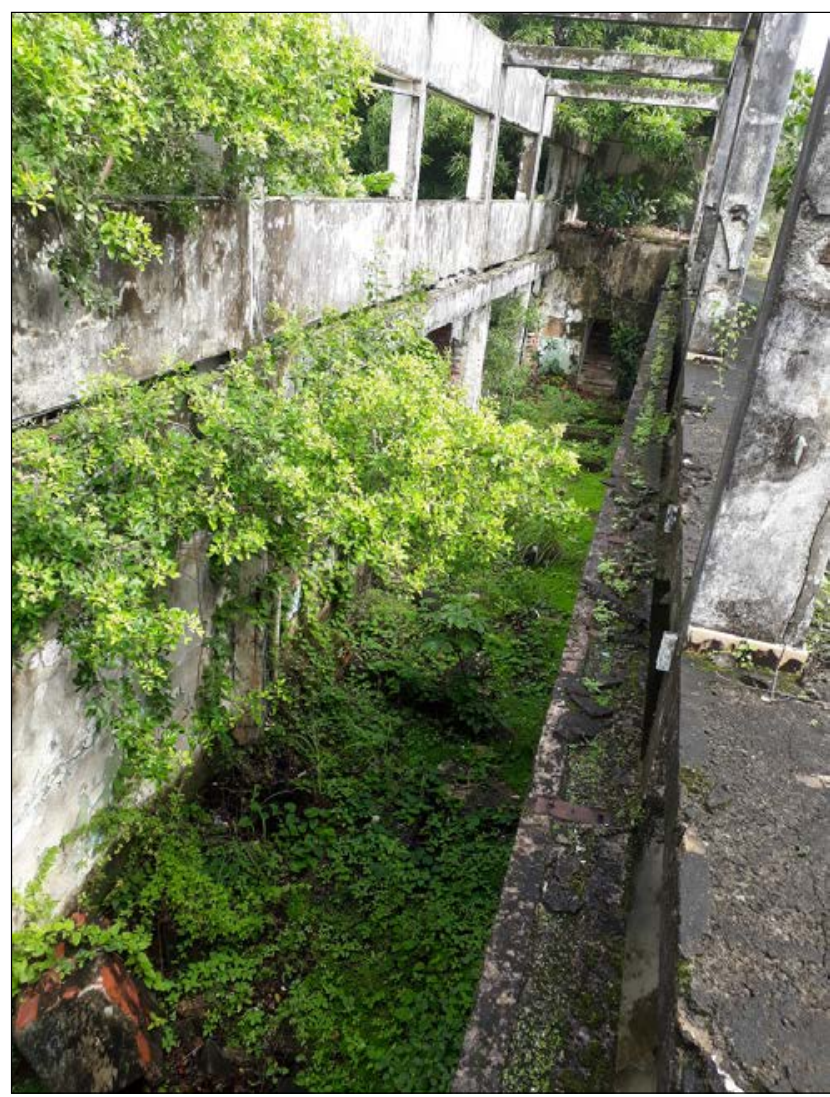

Figura 13 - Parte interna de uma estação desativada nas encostas do manguezal.

$\mathrm{O}$ verde vai crescendo como jardins nas ruínas. Foto: Rafael Palermo Buti (maio 2019).

das contaminações industriais produzidas pelo que Eliete Paraguassu, liderança do quilombo da Ilha de Maré, tem chamado de "assassinos invisíveis" ${ }^{\circ}$.

Dom João foi um engenho de açúcar pertencente a uma renomada família de barões escravocratas (Barickman 1998). Nas margens do rio homônimo, está o porto Dom João, de onde era escoado, pela Baía de Todos os Santos, o açúcar produzido para Salvador. No contexto escravista, o Recôncavo respondia por boa parte da produção nacional de cana-de-açúcar para a exportação. Em 1906, Dom João passa a sediar uma usina de açúcar. A desativação da usina, nos anos 1960, e a compra das terras por parte de novos fazendeiros trouxeram implicações para uma parcela das famílias de trabalhadores que ali viviam, e que foram expulsas entre os anos 1980 e 2000 (Pinto 2016, 2019).

A partir dos anos 2010, o poder público local iniciou um processo de reintegração de posse, determinando o despejo das famílias e a destruição de algumas residências, a incluir dois terreiros de Candomblé. Concomitante ao processo de reintegração de posse e derrubada das casas, a prefeitura passou a acionar a legislação ambiental para justificar a retirada dos moradores da área. Placas foram colocadas ao redor das residências, informando um estatuto jurídico do território até então alheio às concepções locais: Área de Preservação Permanente (APP). Relatórios técnicos passaram a ser produzidos pela SEMAP, justificando a incompatibilidade

6 A noção de racismo e sacrifício ambiental, bem como de assassino invisível, tem sido vocalizada pelas mulheres marisqueiras e lideranças quilombolas da Baía de Todos os Santos, como Eliete Paraguassú, Marizelia Lopes, Joselita Gonçalves e Elionice Sacramento. Sobre o tema, ver Mídia Ninja (2019). 
entre a presença dos pescadores e as áreas de manguezal e beira de rio. É com essa justificativa que a prefeitura judicializou o processo de titulação do território junto ao Instituto Nacional de Colonização e Reforma Agrária (INCRA), aberto pela comunidade em 2013. Em suma, a política municipal do Meio Ambiente é inimiga de Dom João.

Nesse cenário de guerra, nasce a luta quilombola na comunidade, para interromper um ciclo de racismo e expropriação, que sempre marcou o lugar. A luta quilombola nasce a partir da interlocução de seus moradores com outras comunidades quilombolas, pesqueiras e tradicionais do Recôncavo Baiano, engajando três principais grandezas: a justiça fundiária, racial e socioambiental.

\section{RESSURGÊNCIA E "MANQUINTAL"}

Remetido à história do açúcar, Dom João foi o nome da primeira base de exploração do petróleo para fins comerciais no Brasil, o campo Dom João, inaugurado em 1954 (Brito 2008). Foi a descoberta deste campo que reconfigurou o planejamento territorial da região, influenciando a construção de um dos polos petroquímicos mais importantes da América do Sul, a refinaria Landulpho Alves, erguida sobre as áreas de manguezal, na porção sudeste do município ${ }^{7}$. Por conta dos diferentes processos que ocorreram no local, boa parte das áreas residenciais atuais está localizada em regiões de aterro produzidas pela petroleira ao longo de mais de 60 anos de exploração. Embora não esteja em funcionamento, parte das infraestruturas do petróleo e do açúcar continua nas paisagens de Dom João: as ruínas do ancoradouro, as vigas da caldeira de petróleo, a chaminé da usina, o cimento da lavagem de caminhão compõem o ambiente das casas e os caminhos para a maré.

Antes da chegada da Petrobras, parte das atuais áreas residenciais era ambiente de "lama" e "mangue mole", como dizem, lugar impraticável para a ocupação humana. Seguidos processos de aterramento para exploração e transporte do petróleo produziram não somente a contaminação do mangue, a mortandade multiespecífica e o arruinamento das paisagens, mas também a criação de um ambiente favorável à ocupação de humanos e outras espécies florísticas e faunísticas, incluindo os guaiamuns, crustáceos de valor alimentar que vivem em ambientes de transição entre o mangue e a floresta. Trata-se, como relata um morador, de "uma encosta feita com tauá", uma espécie de argila ou areia misturada com dejetos da indústria petroleira e material do mangue escavado e soterrado pelos tratores (Figura 14).

Por ocupar as ruínas do açúcar e do petróleo

7 Informações da Agência Nacional de Petróleo sobre o Campo Dom João podem ser acessadas em ANP (2016). 


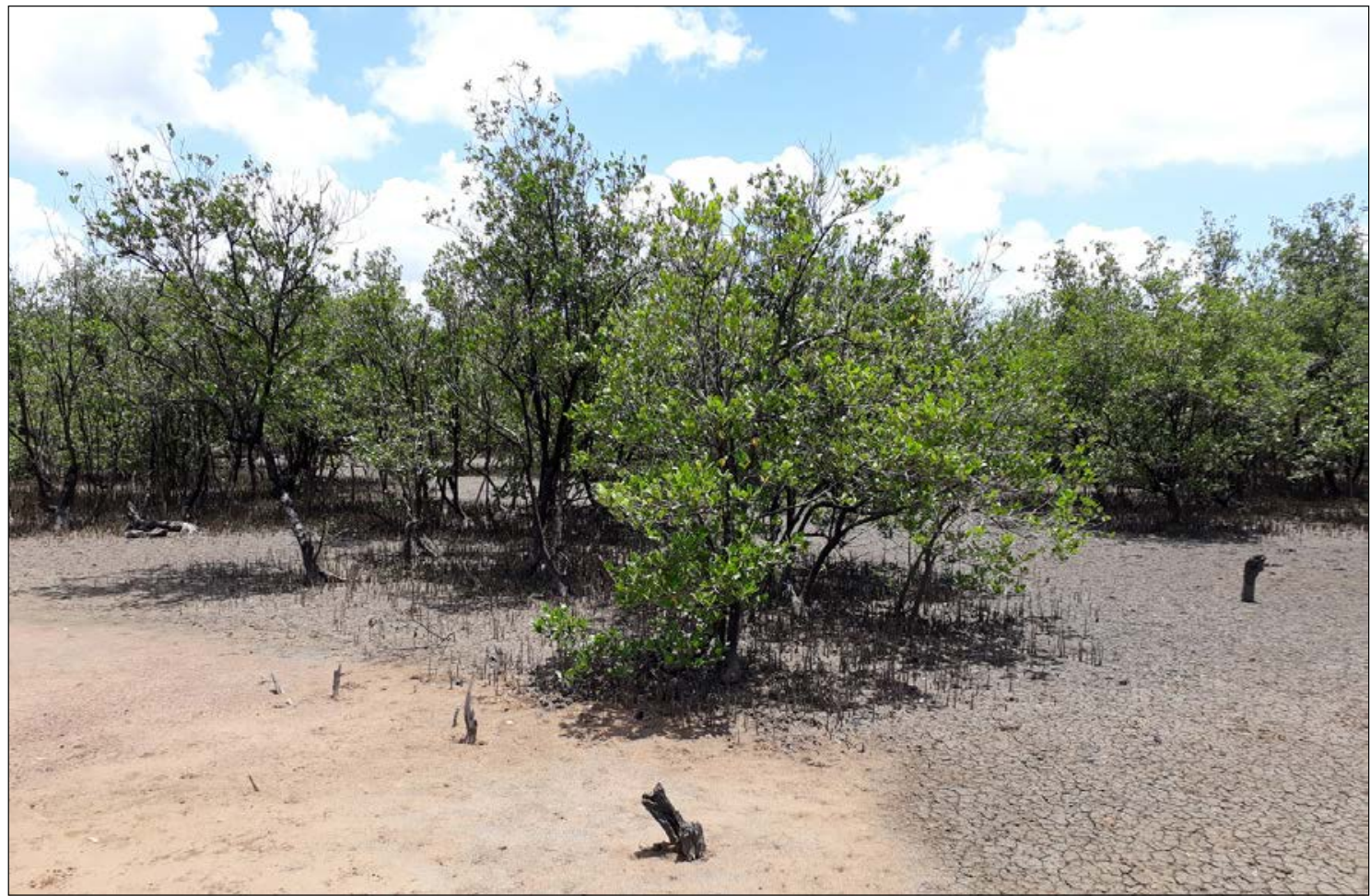

Figura 14 - Limite entre o manguezal e o aterro para a exploração petrolífera. Há muitos aterros como este, que ocuparam áreas de manguezal, formando caminhos de terra firme em meio aos bosques de mangue. Estes lugares produziram ambientes propícios para a ocupação de guaiamuns, que são os crustáceos que vivem em terra firme, em zonas de transição entre o manguezal e a floresta. Nos casos dos aterros, as zonas não são de transição, mas de ruptura. Boa parte destes ambientes de ruptura, hoje desativados, serve de trajeto para pescadores e marisqueiras em direção aos seus lugares de pesca. Eles não são ambientes propícios a caranguejo-uçá, aratus, siris, ostras e sururus, espécies que aí viviam e que perderam a habitabilidade. Foto: Rafael Palermo Buti (out. 2019).

e fazer de um lugar contaminado um ambiente de reflorescimento de vida multiespecífica, moradores de Dom João estão inseridos no que Ana Tsing (2017) chama de ressurgência: entendida como o trabalho de muitos organismos negociando suas diferenças para forjar ajuntamentos multiespécies em meio aos distúrbios de paisagens arruinadas (Tsing 2017). Habitar as ruínas do açúcar e do petróleo implica ressurgir nas paisagens conformadas pelas fazendas e pela indústria petroleira, e propor como vida existir nas paisagens perturbadas (Figura 15).

O berçário de guaiamum criado por José em seu quintal é um destes exemplos de recuperação do manguezal nas ruínas do petróleo (Figura 16). Tratase de uma cavidade de um metro de profundidade por um metro e meio de largura, cercada por tijolos e coberta por uma tela, cavado há mais de vinte anos na antiga viga de aço, que sustentava uma refinaria de petróleo. Ali, este quilombola cuida das fêmeas ao longo dos anos. Alimenta-as, além de regular a água e 


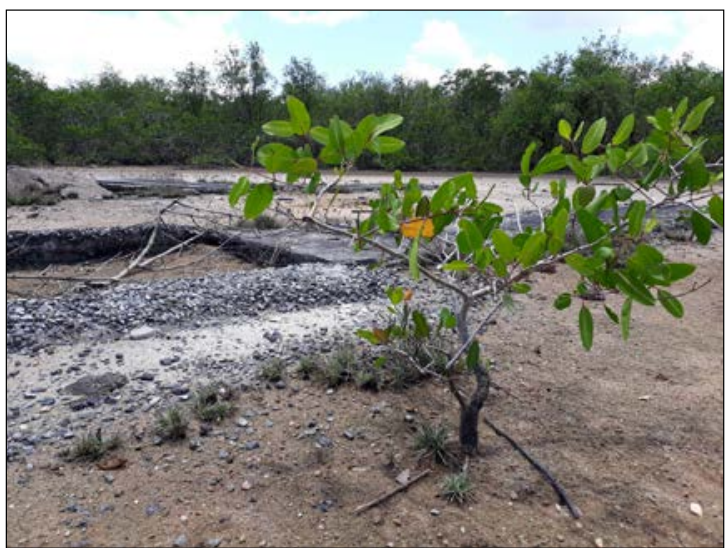

Figura 15 - Uma árvore de mangue vermelho nasce em uma área de aterro. Neste local desativado explorava-se petróleo desde os anos 1960. Antes do aterro, esta era uma área de manguezal úmido, lugar de florescimento dos bosques de mangue vermelho, bem como das espécies de caranguejo-uçá, aratu, ostra e marisco, hoje ausentes. O crescimento desse mangue vermelho sobre o aterro é a retomada de uma árvore expulsa em nova paisagem. Foto: Rafael Palermo Buti (out. 2019).

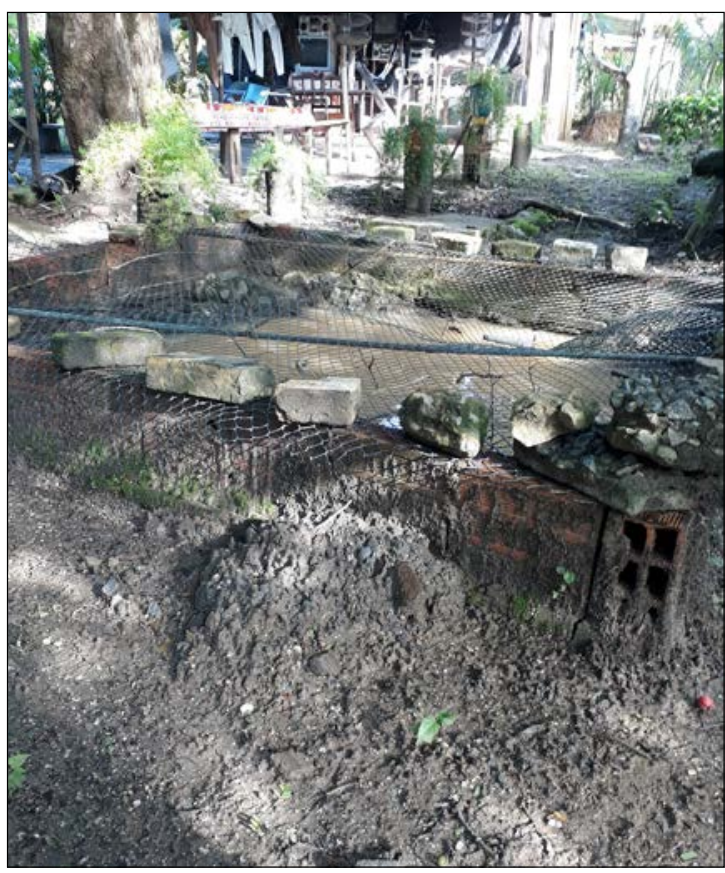

Figura 16 - Berçário do guaiamum no "manquintal" de Dom João. Foto: Rafael Palermo Buti (jun. 2018). manter relação, diálogo e cuidado com os buracos dos guaiamuns do entorno, alguns dos quais, segundo o mesmo, abertos pelos filhotes ali nascidos, que saem espontaneamente do berçário pelas frestas dos tijolos.

O berçário parece configurar uma iniciativa local, criativa e propositiva, de cuidado e conservação do mangue e recuperação da espécie guaiamum por parte de um gaiamunzeiro. Em outras palavras, José é, por conta própria, um pescador-pesquisador do manguezal, preocupado com o presente e futuro da região. Além do berçário, em seu quintal, há inúmeras espécies de árvores, plantas e folhas (Figura 17), plantadas por ele mesmo e por seus parentes ou nascidas de forma espontânea, configurando o que um grupo de estudantes da UNILAB tem chamado de "manquintal": este espaço de vida das populações pesqueiras que conjuga áreas de manguezal com quintais e outros ambientes domésticos (Buti 2019)

O "manquintal" é um lugar multiespecífico e típico dos coletivos marcados pelo que Escobar (2015) chama de "ontologia relacional", onde humanos e não humanos formam parte integral dos mundos, em suas múltiplas inter-relações: o que de alguma forma confunde as fronteiras rígidas demarcadas pelo dualismo ontológico, baseado na separação natureza/cultura, tão presentes nas concepções dos operadores do direito ambiental e do ambientalismo preservacionista(Latour 1994; Little 2002).

8 O "manquintal" surgiu como conceito elaborado durante atividades de campo para a disciplina Laboratório de Saberes, do curso de Licenciatura em Ciências Sociais, da UNILAB. 


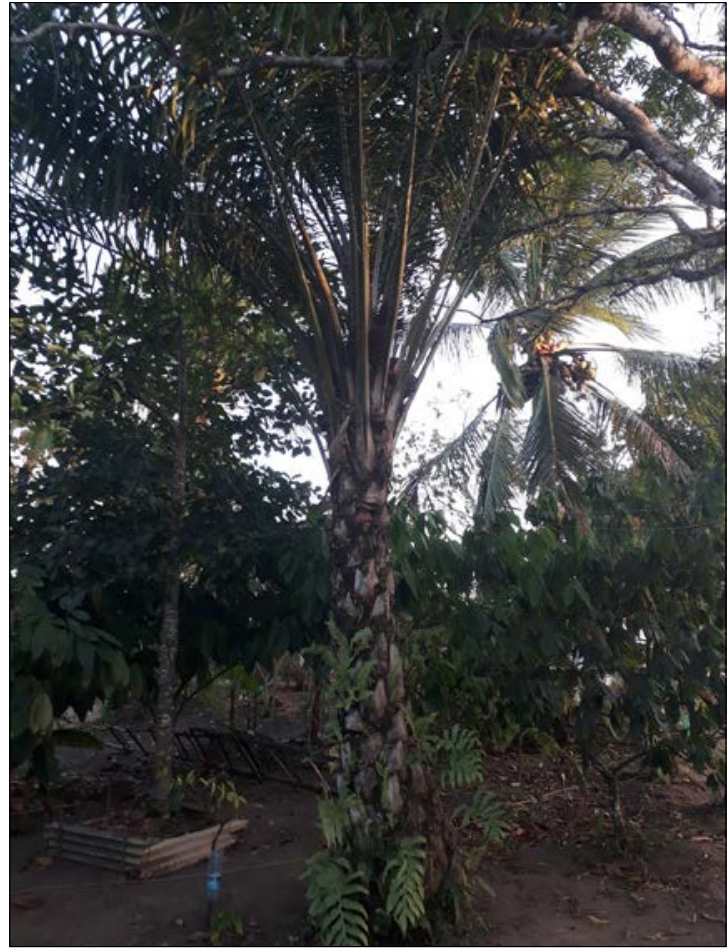

Figura 17 - Dendezeiro (Elaeis guineensis) em "manquintal” de Dom João. O manejo dos dendezeiros faz parte das paisagens afro-brasileiras na Bahia (Watkins 2015), sendo importante também para alimentar os guaiamuns capturados. Ao lado da árvore, fazem companhia um abacateiro (Persea americana) e um coqueiro (Cocos nucifera), plantados pelos quilombolas. Estão em uma área de aterro devastada, que servia de base de refino ao petróleo até os anos 1980. A ocupação dos quilombolas contribuiu para a sociobiodiversidade em uma paisagem perturbada. Foto: Rafael Palermo Buti (set. 2019).

São justamente as concepções assentadas na separação entre natureza e cultura que vêm fundamentando a justificativa da prefeitura para a retirada dos moradores de Dom João. A SEMAP acusa os moradores de serem degradadores do ambiente, por ocuparem uma Área de Preservação Permanente(APP). Os relatórios produzidos pelo órgão não levam em conta a relação vital que liga humanos e pescadores com as áreas de manguezal da cidade, bem como a contribuição dos habitantes de Dom João para a recuperação de uma área degradada pela cadeia petrolífera, escamoteando a condição feita e arruinada pelo petróleo em relação às paisagens do lugar, bem como a escala de devastação impetrada pelos vazamentos. Não levam em consideração também os direitos de autodeterminação das comunidades quilombolas, que, além de possuírem ancestralidade negra e vinculação com o território, são reféns históricos da desigualdade fundiária e racial na cidade (Figura 18).

É para descrever a conformação dessa paisagem em Dom João que nasce o termo petroceno: com ele, é possível argumentar sobre a escala infinitamente maior de degradação do petróleo em relação aos impactos

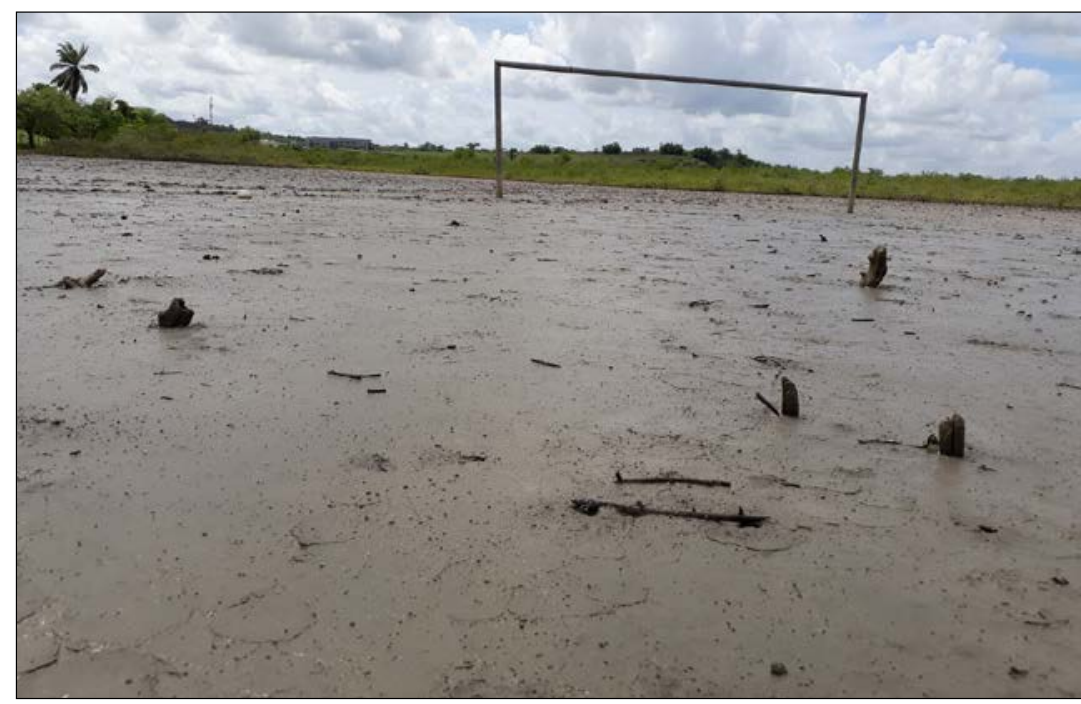

Figura 18 - Campo de futebol em uma prainha de manguezal na Baixa Fria, território contíguo ao Marapé.

É possível jogar somente em condições especiais, quando a maré está muito baixa. É um exemplo de

criatividade e inventividade diante das finitudes impostas pela cadeia petrolífera. É um exemplo de como a vida deve prosseguir nas ruínas. Trata-se de um gol na/da perturbação. Foto: Rafael Palermo Buti (abr. 2018). 
gerados pelos pescadores, bem como sobre o uso assimétrico da legislação ambiental como dispositivo de exclusão da população pesqueira, negra e pobre da cidade, em benefício das elites petroleiras, políticas e agrárias locais. $\mathrm{O}$ argumento preservacionista da Área de Preservação Permanente proíbe os pescadores de habitarem os manguezais e as margem do rio, ignorando o fato de este mesmo território (incluindo a própria "margem" do rio) ser, em boa parte, uma infraestrutura do petróleo. Ou seja, o argumento do Meio Ambiente encoberta a dimensão petroleira dos lugares (o petroceno) e pouca força parece ter para coibir os vazamentos, além de excluir pescadores dos ambientes que, sobretudo, ajudam a cuidar. É necessário, definitivamente, revelar, para desnaturalizar, o petroceno, em benefício daqueles que o habitam.

\section{O RECADO VEIO ANTES}

No Recôncavo Baiano existe um olhar atento e engajado contra a contaminação e a perturbação dos manguezais. Este olhar vem do quilombo (Figuras 19 e 20). Produzindo a crítica ao latifúndio e ao racismo, é também contra a perturbação do petróleo que a comunidade de Dom João se (re)volta.

Se na obra fundamental "A queda do céu" (Kopenawa \& Albert 2015), o xamã yanomami Davi Kopenawa traz o "recado da mata" (Viveiros de Castro 2015) como forma de mostrar que o projeto ecocida do "branco" contra os povos indígenas e as florestas

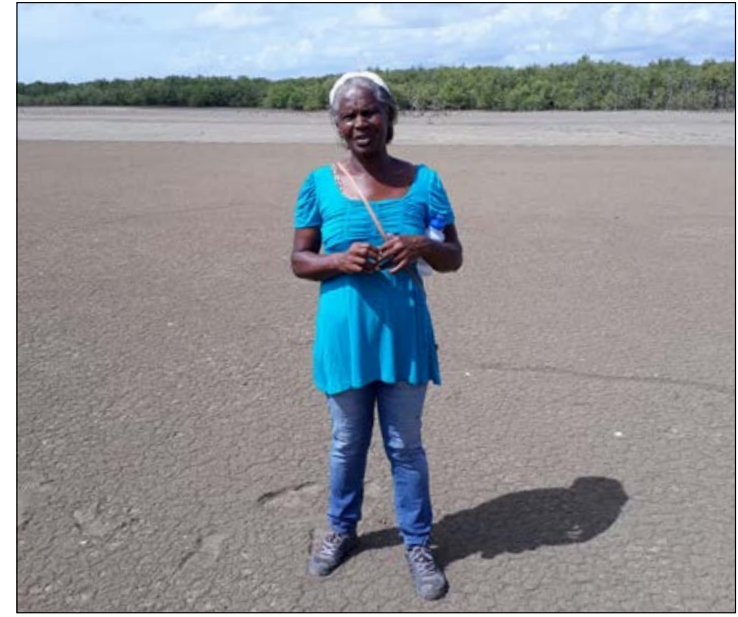

Figura 19 - Dona Joselita Gonçalves, conhecida por Dona Joca, é liderança quilombola em Dom João. Nesta imagem, ela está cheia de vida sobre um mangue morto. Este lugar era ocupado por bosques de mangue vermelho, que foram exterminados aos poucos. Neste dia, ela conduziu uma atividade pedagógica chamada Caminhaula, em janeiro de 2020, ensinando sobre território pesqueiro e racismo ambiental. Segundo Dona Joca, a área onde estávamos pisando é um "cemitério do mangue". Só foi possível transitar nele porque a maré estava muito baixa. Em condições normais, o chão é bastante úmido, dificultando a caminhada. Foto: Rafael Palermo Buti (jan. 2020).

determinará também o fim da humanidade (incluindo o povo branco), são as lideranças quilombolas pesqueiras do Recôncavo Baiano quem trazem o "recado do mangue". Mesmo antes da maior catástrofe socioambiental ocorrida na costa brasileira a partir de agosto de 2019 (quando as águas atlânticas trouxeram o petróleo para terra-firme), mulheres e homens da Baía de Todos os Santos vocalizavam esse recado. Em suas praias e manguezais, o vazamento de petróleo chegou antes. Diante dos mecanismos históricos de silenciamento a que são submetidas, é preciso levá-las a sério porque é um recado também sobre o presente e o futuro de todo(s) o(s) mundo(s): pois a "maré é uma só". 


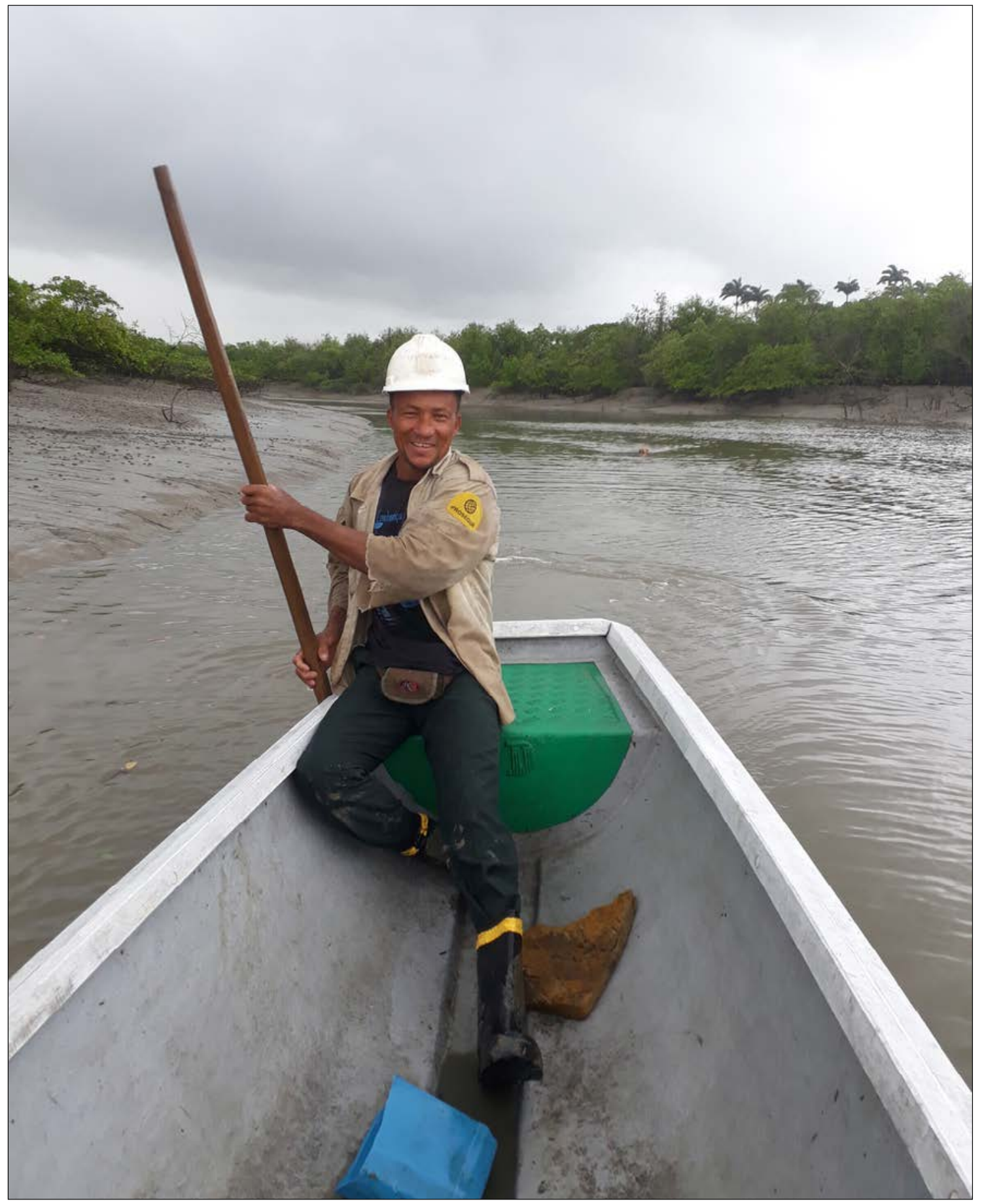

Figura 20 - José Américo Borges, gaiamunzeiro e liderança quilombola. Na imagem, ele está navegando pelas águas do rio Dom João, a caminho de uma das áreas de captura de guaiamum. Do Sr. Zé vem um dos recados do mangue. Segundo ele, nas prainhas e nas áreas contaminadas, é necessário replantar as árvores de mangue com amor, "se não, não vinga”. Foto: Rafael Palermo Buti (out. 2019). 


\section{REFERÊNCIAS}

Agência Nacional do Petróleo, Gás Natural e Biocombustíveis (ANP). 2016. Dom foão. Disponível em: http://www.anp.gov.br/images/planos_desenvolvimento/Dom_Joao.pdf. Acesso em: 20 maio 2020.

Associação Quilombola Porto Dom João. 2018. Quilombo Dom João em defesa do meio ambiente e contra o derramamento e contaminação de petróleo. Carta Aberta da Comunidade Quilombola Dom João sobre o derramamento de petróleo ocorrido no dia 16 de maio de 2018. Disponível em: https://pt.scribd.com/document/412560515/Carta-Do-Quilombo-Dom-Joao. Acesso em: 18 maio 2020.

Buti, R. 2019. O “Gaiamum Petroleiro", o "Meio Ambiente”, o "Quilombo" e o "Manquintal": notas sobre (des)fazer mundos nas paisagens de mangue no Recôncavo da Bahia. Anais da VII Reunião de Antropologia da Ciência e da Tecnologia.

Barickman, B. J. 1998. Até a véspera: o trabalho escravo e a produção de açúcar nos engenhos do Recôncavo Baiano (1850-1881). Afro-Ásia (21-22):177-238. DOI: http://dx.doi.org/10.9771/aa.v0i21-22.20967

Brito, C. 2008 A PETROBRAS e a gestão do território no Recôncavo Baiano. Salvador: EDUFBA.

Escobar, A. 2015. Territorios de diferencia: la ontología política de los "derechos al territorio". Cuadernos de Antropología Social 35:89-100.

Gragnani, J. 2019. Essenciais para o planeta, manguezais no Nordeste são ‘sufocados’ por petróleo. G1. Disponível em: https://g1.globo.com/natureza/desastre-ambiental-petroleo-praias/noticia/2019/10/25/ essenciais-para-o-planeta-manguezais-no-nordeste-sao-sufocados-por-petroleo.ghtml. Acesso em: 18 maio 2020.

Grupo de Pesquisa a Geografia dos Assentamentos na Área Rural (GeografAR). 2015. Comunidade negra rural quilombola Porto de Dom foão. Relatório Preliminar. Salvador: UFBA. 
Haraway, D. 2015. Anthropocene, Capitalocene, Plantationocene, Chthulucene: Making Kin. Environmental Humanities 6:159-165.

Hatje, V., M. Bícego, G. Carvalho, e J. Andrade. 2009. Contaminação química, in Baía de todos os santos: aspectos oceanográficos. Editado por V. Hatje e J Andrade, pp. 243-298. Salvador: EDUFBA.

Intervozes. 2020. Vozes Silenciadas: a cobertura do vazamento de petróleo na costa brasileira. Disponível em: https://intervozes.org.br/publicacoes/vozes-silenciadas-petroleo/. Acesso em: 02 out. 2020.

Kopenawa, D., eB. Albert. 2015. A queda do céu: palavras de um xamã yanomami. São Paulo: Companhia das Letras.

Latour, B. 1994. Jamais fomos modernos. São Paulo: Ed. 34.

Little, P. 2002. Territórios sociais e povos tradicionais no Brasil: por uma antropologia da territorialidade. Anuário Antropológico 28(1):251-290.

Mídia Ninja. 2019. Assassino invisível - lixo industrial na Ilha de Maré chega a níveis mortais. Disponível em: https://midianinja.org/news/assassino-invisivel-lixo-industrial-na-ilha-de-mare-chega-a-niveismortais/. Acesso em: 07 jul. 2020.

Nodari, A. 2018. Recipropriedade. Piseagrama 12:26-35.

Pinto, N. J. 2016. Experiência e memória: uma etnografia da experiencia de migração forçada em Dom João em São Francisco do Conde-BA. Monografia de Trabalho de Conclusão de Curso, Bacharelado em Humanidades, Universidade da Integração Internacional da Lusofonia Afro-brasileira, Salvador.

Pinto, N. J. 2019. Território falante: uma escrevivência das experiências e (r)existências do Quilombo Dom João. Monografia de Trabalho de Conclusão de Curso, Licenciatura em Ciências Sociais, Universidade da Integração Internacional da Lusofonia Afro-brasileira, Salvador. 
Sansone, L. 2007. Contraponto baiano do açúcar e do petróleo: São Francisco do Conde, Bahia 50 anos depois, In Projeto Unesco no Brasil: textos críticos. Editado por C. Pereira e L. Sansone, pp. 194-218. Salvador: Edufba.

Santos, B. S. 2017. Da Ilha da Maré a outro mundo possível. Outras Palavras. Disponível em: https:// outraspalavras.net/brasil/boaventura-da-ilha-da-mare-a-outro-mundo-possivel/. Acesso em: 18 maio 2020.

Santos, J. R. 1979. O dia em que o povo ganhou. Rio de Janeiro: Civilização Brasileira.

Silveira, P.; Buti, R. 2020. A vida e a morte dos guaiamuns: antropologia nos limites dos manguezais. Anuário Antropológico 45(1):117-148.

Soares, M. O., C. E. P. Teixeira, L. E. A. Bezerra, S. Rossi, T. Tavares, e R. M. Cavalcante. 2020. Brazil oil spill response: Time for coordination. Science 367(6474):155. DOI: https://doi.org/10.1126/science.aaz9993

Stengers, I. 2015. No tempo das catástrofes. Rio de Janeiro: Cosac \& Naif.

Tsing, A. L. 2017. A threat to Holocene resurgence is a threat to livability, in The anthropology of sustainability. Editado por M. Brightman e J. Lewis, pp. 51-65. New York: Palgrave Macmillan. DOI: https://doi.org/10.1057/978-1-137-56636-2_3

Tsing, A. L. 2019a. Viver nas ruínas - paisagens multiespécies no Antropoceno. Brasília: Mil Folhas.

Tsing, A. L. 2019b. Comunicação. Anais da VII Reunião de Antropologia da Ciência e Tecnologia.

Viana Filho, L. 1984. Petroquímica e industrialização na Bahia - 1967-1971. Brasília: Mil Gráficas.

Viveiros de Castro, E. 2015. O recado da mata (Prefácio), in A queda do céu: palavras de um xamã 
yanomami. Editado por Davi Kopenawa e Bruce Albert, pp. 11-42. São Paulo: Companhia das Letras.

Watkins, C. 2015. African Oil Palms, Colonial Socioecological Transformation and the Making of an Afro-Brazilian Landscape in Bahia, Brazil. Environment and History 21(1):13-42. 